УДК 316.356.4:316.722

DOI https://doi.org/10.32837/apfs.v0i27.930

\author{
В. А. Плющ \\ ORCID ID: https://orcid.org/0000-0002-6945-4233 \\ аспірант \\ Інституту соціологї Національної академї наук України
}

\title{
СОЦІОЛОГІЧНІ МОДЕЛІ СОЦІОКУЛЬТУРНОЇ АДАПТАЦІЇ СУЧАСНИХ МІГРАНТІВ В ІНШОКУ ЛЬТУРНОМУ СЕРЕДОВИЩІ
}

\begin{abstract}
Питання адаптації мігрантів в іншокультурному середовищі посідають важливе місце в дослідженнях процесів міграції, оскільки саме успішна адаптація мігрантів до умов та вимог приймаючого суспільства дасть змогу забезпечити плідне, взаємнокомфортнеміжкультурнеспівіснування. Дослідники багатьох дисциплін аналізують наявні моделі адаптації мігрантів та проводять порівняння ступеня впливу тих чи тих чинників на характер міжкультурної взаємодії. Одним із нагальних питань у вітчизняній соціології $€$ узагальнення наявних зарубіжних та вітчизняних теоретичних моделей адаптації мігрантів в іншокультурному середовищі.

Мета статті полягає в огляді напрацьованої соціологічної спадщини теоретичних моделей соціокультурної адаптації мігрантів в іншокультурному середовищі, виробленні узагальненої типологізації моделей адаптації мігрантів від початку XX століття до сьогодення.

$\mathrm{y}$ дослідженні автор буде спиратись на публікації таких авторів, як В. Томас, Ф. Знанецький, Р. Редфілд, Р. Лінтон, М. Герсковіц, Р. Парк, Дж. Беррі, Ф.В. Рудмін, М. Кларк, Ш. Кауфман, Р. Пірс, А. Рудіґер, С. Спенсер, Т. Горовіц, В. Володько, О. Ровенчак.
\end{abstract}

Міграційна проблематика сьогодні вважається однією 3 найактуальніших у світі. У XXI столітті практично не залишилось країн, котрі не стикалися б із проблемами прибуття, виїзду або транзиту власного чи прибулого населення, з проблемами пристосування та органічного включення останнього у суспільне життя. 3 посиленням глобалізації усіх процесів суспільного розвитку, прискоренням транссуспільної мобільності, міждержавних взаємин тощо значення міграційних процесів стрімко зростає.

3 моменту прибуття мігрантів до іншої країни, регіону чи спільноти починається процес їх адаптації до нового соціокультурного середовища 3 його культурними, політичними, правовими, релігійними, психологічними та іншими необхідними для існування особливостями, одночасно постають проблеми, що пов'язані 3 ними. В науковій літературі прийнято виділяти окремі види адаптації мігрантів, зокрема економічну, політичну, трудову, етнічну, релігійну, освітню, інформаційну, соціальну, культурну, психологічну, кожна з яких є вагомою та заслуговує поглибленого вивчення відповідними галузями знань [10, с. 112].

Від початку формування соціологічної науки увагу аналітиків привертали саме проблеми, пов'язані із соціокультурною адаптацією. Нею переймались такі відомі соціологи, як Р. Парк, Ф. Знанецький, В. Томас. У даній йтиметься про адаптацію мігрантів в іншокультурному середовищі, отже, предметною цариною цього дослідження буде виступати соціокультурна адаптація, що охоплює соціальну, культурну, побутову та психологічну сфери взаємодії мігрантів з приймаючою спільнотою.

Історично склалось так, що увага дослідників до проблем соціокультурної адаптації мігрантів пов'язана з аналізом акультурації, або міжкультурної адаптації. В соціологічній літературі термін «акультурація» визначає «процес взаємовпливу культур, за якого здійснюється запозичення елементів однієї культури іншою, повністю чи частково засвоюються правила, норми та цінності чужої культури, її моральні та матеріальні здобутки, котрі змінюються під впливом нових соціокультурних умов" [14, с. 7].

Згідно з Р. Редфілдом, Р. Лінтоном та М. Герсковіцом, «акультурація охоплюе ті явища, які виникають, коли групи людей, що мають різні культури, постійно контактують між собою, 3 подальшими змінами в оригінальних моделях культури однієї або обох груп» [5, с. 149].

Визначення ж адаптації мігрантів трактується як «комплекс особливостей вчинків та поведінки мігрантів, що має соціокультурне походження, завдяки якому особа чи група осіб забезпечує собі успіх у конкуренції з представниками інших етнічних груп, які спільно проживають на одній території певної держави» [13, с. 88].

Канадський соціальний психолог Дж. Беррі зіставляє ці два поняття та дає пояснення їх взаємозалежності та взаємозаміни, оскільки адаптація, за визначенням ученого, є «стратегією самого процесу акультурації та безпосередньо їі результатом» (рис. 1) [1, с. 496].

Дослідник поділяе адаптацію на два види, а саме соціокультурну та психологічну. 3 точки 


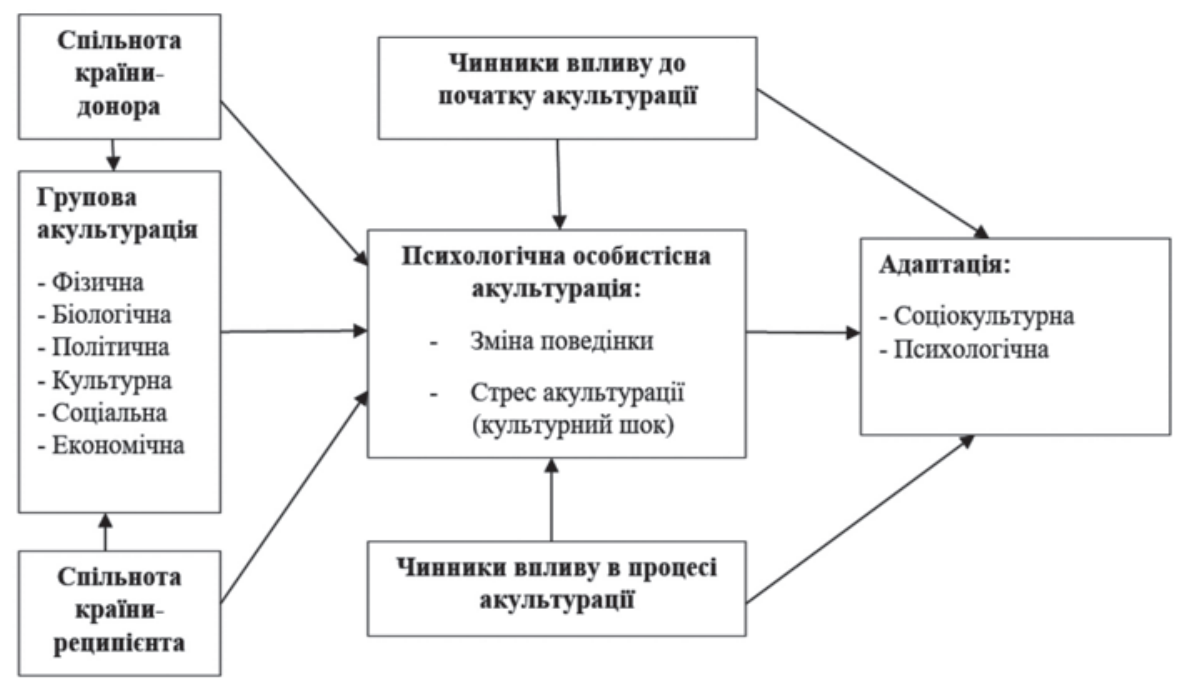

Рис. 1. Адаптація як стратегія та результат акультурації за Дж. Беррі, 1987 рік

зору соціальної психології, психологічна адаптація пов'язана зі взаємодією особи й соціального середовища, що приводить до оптимального співвідношення цілей і цінностей особи та групи. Цей вид адаптації припускає пошукову активність особи до самоідентифікації, усвідомлення нею свого соціального статусу i соціально-рольової поведінки, її місце в процесі виконання спільної діяльності, власне ставлення до норм, цінностей і традицій соціальної групи [12, с. 91].

Під соціокультурною адаптацією вітчизняні соціологи В. Володько і О. Ровенчак розуміють «процес та результат пристосування мігранта до нового соціокультурного середовища, що передбачає взаємне засвоєння чи відторгнення нових соціальних та культурних норм, цінностей, способів поведінки, притаманних мігранту та приймаючій спільноті» [11, с. 192].

Загалом соціокультурна адаптація мігранта, на думку Дж. Беррі, стосується двох проблем: по-перше, підтримки своєї культури, тобто того, якою мірою зберігається власна культурна ідентичність мігранта в новому іншокультурному середовищі; по-друге, участі в міжкультурних контактах або ступеня залучення мігранта до культури приймаючої спільноти. Отже, згідно з Дж. Беррі, необхідно з'ясувати позицію індивіда стосовно його ставлення до цінностей власної культури і необхідності її збереження для розвитку його етнокультурної ідентичності; ставлення індивіда до групи приймаючого середовища: наскільки взаємодія з членами іншокультурної групи є цінною і бажаною для індивіда. Якщо обмежити відповіді на ці питання відповідями «так» або «ні», Дж. Беррі отримує чотири адаптаційні моделі акультурації, котрі в соціологічній літературі прийнято називати моделями адаптації, а саме моделі асиміляції, інтеграції, сепарації та маргіналізації [1, с. 496].

Модель асиміляції передбачає, що мігрант зорієнтований на ідентифікацію з новою культурою, засвоєння культурних цінностей та поступове заміщення ними цінностей власної культури.

Модель сепарації (сегрегації) припускає, що мігрант відхиляє культуру приймаючого середовища і зберігає свої культурні цінності.

Модель маргіналізації означає, що мігрант не ідентифікує себе з жодною культурою. Це може бути результатом неможливості підтримки власної культурної ідентичності й відсутності бажання встановлювати позитивні відносини з групою приймаючого середовища.

Модель інтеграції передбачає, що мігрант ідентифікує себе як із власною, так і з приймаючою культурою, зберігаючи власну культурну спадщину разом із доброзичливим ставленням до культури країни-реципієнта.

Сьогодні окрім типології адаптаційних моделей Дж. Беррі, в науковій літературі налічується більше 100 варіацій моделей адаптації, що пропонуються вченими різних гуманітарних дисциплін (соціології, психології, антропології тощо). Зокрема, норвезький соціолог Ф.В. Рудмін структурував ïх через згаданий конструкт Дж. Беррі чотирьох моделей адаптації залежно від відносної ваги власної культури (ВК) і приймаючої культури (ПК). Ці чотири адаптаційні моделі, котрі ми в подальшому будемо називати класичними, позначені так:

1) - ВК $+\Pi К$, згідно з якою приймаюча культура є вагомішою за власну;

2) +ВК -ПК, згідно 3 якою власна культура мігранта є вагомішою за приймаючу культуру;

3) + ВК $+\Pi К$, згідно з якою обидві культури мають рівноцінну вагу для мігранта; 


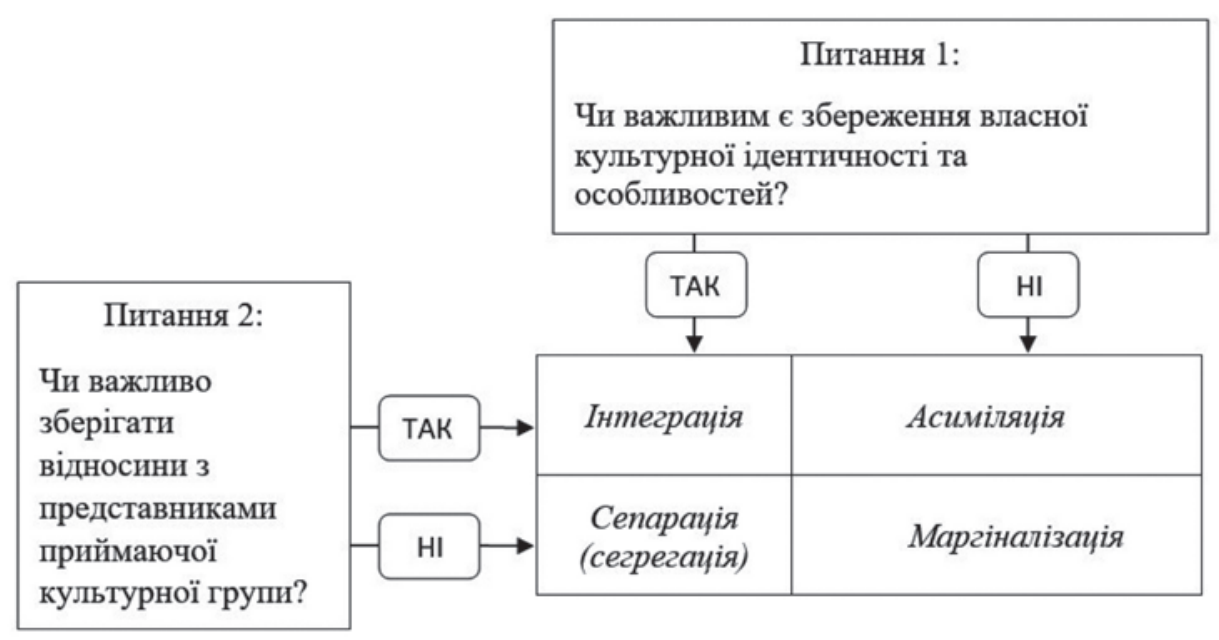

Рис. 2. Алгоритм побудови конструкту чотирьох моделей адаптації Дж. Беррі

4) -ВК -ПК, згідно з якою жодна культура не $є$ прийнятною для мігранта [8, с. 6].

Анотована бібліографія теоретичних досліджень в галузі соціології, психології, антропології, лінгвістики та інших соціальних дисциплін щодо можливих адаптаційних моделей мігрантів у приймаючому іншокультурному середовищі від початку XX століття до сьогодення наведена в табл. 1. У своїх роботах «Критика історії акультурації: психологія асиміляції, сепарації, інтеграції та маргіналізації» та «Каталог конструктів акультурації: Опис 128 моделей» Ф.В. Рудмін звертається до критичного аналізу кожної з вищезгаданих концепцій, ми ж розглянемо лише декілька найвідоміших з них та найбільш дотичних до нашого дослідження [7; 8].

Одними з перших науковців, які теоретизували основні індивідуальні адаптаційні реакції мігрантів в іншокультурному середовищі, були соціологи В. Томас і Ф. Знанецький, які на початку $\mathrm{XX}$ століття вивчили це питання в роботі «Польський селянин в Європі та Америці» Науковці стверджували, що культура складається зі спільних апперцептивних процесів, таких як звички, асоціації, погляди й переконання, які називаються схемами та присутні в будь-якому стабільному соціальному середовищі. Так, на основі емпіричних досліджень щодо польських мігрантів США дослідниками були виокремлені три моделі адаптаційних реакцій мігрантів залежно від їх рівня страху перед змінами чи рівня цікавості щодо цих змін [9, с. 1854-1856].

1) Богемна реакція $(-\mathrm{BК}+\Pi К)$, згідно з якою іммігрант має низький рівень страху і високий рівень цікавості до змін, що стимулює його до пошуку змін і пристосування до будь-якого соціального контексту, однак за рахунок дезорганізації осо- бистості. Відмовившись від культурних «схем» меншості і завжди приймаючи нові, особистість богемного типу може добре асимілюватися з приймаючою культурою.

2) Міщанська реакція (+ВК -ПК), згідно 3 якою іммігранти мають високий рівень страху і низький рівень цікавості до змін, дотримуючись культурних та соціальних традицій і відкидаючи сучасні зміни та досягнення, отже, тяжко адаптуючись до нових соціокультурних умов.

3) Творча реакція $(+\mathrm{BK}+\Pi К)$, згідно з якою іммігранти мають баланс рівня страху і цікавості, отже, прагнуть збалансованих змін, одночасно підтримуючи і змінюючи власну культуру, пристосовуючись до нового соціокультурного середовища.

У 1928 році американський соціолог Роберт Парк, досліджуючи расові проблеми міжкультурної взаємодії в американських містах, розробляє теорію асиміляції, згідно з якою будь-який індивід, котрий за власним бажанням або проти нього знаходить себе в ситуації існування на межі двох різних культур, проходить процес адаптації на шляху до пристосування до полікультурних умов. Відповідно до концепції Р. Парка, існує чотири адаптаційні стани мігранта, а саме перехідний, сепараційний, гібридний та стан асиміляції [4, с. 881-892].

1) Перший стан є перехідним (+ВК - ПК) від приймаючої культурної спільноти та збереження культурних кодів власної.

2) Другий можливий стан асиміляції $(-\mathrm{BК}+\Pi К)$ в новий суспільний порядок характеризується прийняттям чужої культури та поступовим відчуженням від власної.

3) Третій можливий стан сепарації (-ВК-ПК)характеризуєтьсязвільненнямвідкордонів, 
Таблиця 1

Узагальнена таблиця моделей адаптації з 1918 до 2011 року

\begin{tabular}{|c|c|c|c|c|}
\hline Рік, прізвище автора & $-\mathrm{BK}+\Pi K$ & $+\mathrm{BK}-\Pi K$ & $+\mathrm{BK}+\Pi K$ & -ВК -ПК \\
\hline 1 & 2 & 3 & 4 & 5 \\
\hline \multicolumn{5}{|c|}{ Адаптаційна модель } \\
\hline $\begin{array}{l}\text { 1918, Томас, } \\
\text { Знанецький }\end{array}$ & Богемна реакція & Міщанська реакція & Творча реакція & - \\
\hline 1920, Pocc & Акомодаційна & Толерантна & Компромісна & - \\
\hline 1920, Берксон & Американізаційна & $\begin{array}{c}\text { Федерація національ- } \\
\text { ностей }\end{array}$ & $\begin{array}{c}\text { Плавильний котел } \\
\text { культур }\end{array}$ & - \\
\hline 1923, Бартлет & Заміщення & Часткове заміщення & Змішування & - \\
\hline 1924, Міллер & Плавильний котел & Сегрегація & Опосередкованість & - \\
\hline 1932, Турнвальд & Реінтеграція & Симбіоз & Гібридність & Перехідний період \\
\hline 1928, Парк & Імітація, інтеграція & Сепарація & Культурна гібридність & Перехідний стан \\
\hline 1934, Гоффман & $\begin{array}{l}\text { Неприйняття } \\
\text { іноземної мови }\end{array}$ & Тільки іноземна мова & $\begin{array}{c}\text { Пропорційний } \\
\text { білінгвізм }\end{array}$ & - \\
\hline 1934, Браун & - & Ізоляція & Субординація & Асиміляційний синтез \\
\hline $\begin{array}{l}\text { 1936, Редфілд, Лінтон, } \\
\text { Герсковіц }\end{array}$ & Прийняття & Реакція & Адаптація & - \\
\hline 1939, Чілд & Повстанська реакція & Інтергрупова реакція & Подвійна реакція & Апатична реакція \\
\hline \multicolumn{5}{|l|}{ 1940, Сроул } \\
\hline 1940, Слоткін & $\begin{array}{c}\text { Повстанська, } \\
\text { маргінальна }\end{array}$ & - & $\begin{array}{c}\text { Змішана, авантюррна, } \\
\text { незалежна, акульту- } \\
\text { рована }\end{array}$ & $\begin{array}{l}\text { Неорганізована, } \\
\text { емансипована }\end{array}$ \\
\hline 1943, Девро, Лоеб & - & Захисна ізоляція & $\begin{array}{c}\text { Прийняття нових } \\
\text { цінностей } \\
\end{array}$ & $\begin{array}{c}\text { Дисоціативна негативна } \\
\text { акультурація }\end{array}$ \\
\hline 1945, Сентер & Приймати & Утримувати & - & Розвивати \\
\hline 1945, Вітр & Асиміляція & $\begin{array}{l}\text { Войовничість, } \\
\text { відокремлення }\end{array}$ & Плюралізм & - \\
\hline 1947, Кампазі & Успішна & Мінімальна & Дилетанстська & - \\
\hline 1948, Левін & Негативний шовінізм & Шовінізм & $\begin{array}{c}\text { Подвійна } \\
\text { толерантність }\end{array}$ & Маргінальність \\
\hline 1949, Іхайзер & Імітування & Відхилення & Псевдорішення & Заперечення \\
\hline 1949, Гордон & Маргінальність & Збереження & Ствердження & - \\
\hline 1949, Богардус & Нав'язливість & - & Сліпа, демократична & - \\
\hline 1951, Воже & Маргінали & Місцеві & Видозмінені & - \\
\hline 1951, Беррі & Асиміляція & Сегрегація & $\begin{array}{c}\text { Плюралізм, } \\
\text { стратифікація }\end{array}$ & Об’єднання, злиття \\
\hline $\begin{array}{c}\text { 1952, Шпіндлер, } \\
\text { Голдсмідт }\end{array}$ & Акультуровані & Місцеві & Перехідні & Культ Пейота \\
\hline 1952, Зажонк & Підпорядкування & Агресія & Фрустрація & - \\
\hline 1952, Ітон & Асиміляція & $\begin{array}{l}\text { Контрольована } \\
\text { акультурація }\end{array}$ & - & Маргінальність \\
\hline 1952, Айзенстадт & Невпевнений перехід & Традиційність & Впевнений перехід & Виживання \\
\hline 1952, Айзенстадт & $\begin{array}{c}\text { Самозмінювана } \\
\text { згуртована етнічна група }\end{array}$ & $\begin{array}{c}\text { Ізольовані стабільні } \\
\text { та активні сім’ї } \\
\end{array}$ & $\begin{array}{c}\text { Згуртована етнічна } \\
\text { група } \\
\end{array}$ & $\begin{array}{c}\text { Ізольована } \\
\text { апатична сім'я }\end{array}$ \\
\hline 1952, Jii & Акультурована особа & Сегрегована особа & Маргінальна особа & - \\
\hline 1952, Білс & Прийняття & Реакція & Синкретизм & Переформулювання \\
\hline 1953, Віллі & Колонія & Біженці & Змішування & - \\
\hline 1953, Тафт & Монізм & Плюралізм & Інтеракціонізм & - \\
\hline 1953, Сімпсон, Йінгер & Асиміляціоніст & $\begin{array}{l}\text { Сецесіоніст, } \\
\text { войовничий }\end{array}$ & Плюраліст & Амбівалентний \\
\hline $\begin{array}{l}\text { 1954, Барнетт, Брум, } \\
\text { Сігель, Вогт, Ватсон }\end{array}$ & $\begin{array}{c}\text { Прогресивне } \\
\text { пристосування }\end{array}$ & Реактивна адаптація & $\begin{array}{c}\text { Стабілізований } \\
\text { плюралізм }\end{array}$ & $\begin{array}{c}\text { Культурна } \\
\text { дезінтеграція }\end{array}$ \\
\hline 1955, Спіро & Асиміляція & Солідарність & Акультурація & Декультурація \\
\hline 1955, Антоновський & $\begin{array}{c}\text { Активна загальна } \\
\text { спрямованість }\end{array}$ & $\begin{array}{c}\text { Активна/пасивна } \\
\text { орієнтація на іудаїзм }\end{array}$ & Дуальна орієнтація & $\begin{array}{l}\text { Амбівалентна, пасивна } \\
\text { загальна спрямованість }\end{array}$ \\
\hline 1956, Зубржиских & Асиміляція & - & Акомодація & Конфлікт \\
\hline 1956, Коен & Асиміляція & Виживання & - & Байдужість \\
\hline
\end{tabular}


Продовження таблиці 1

\begin{tabular}{|c|c|c|c|c|}
\hline 1 & 2 & 3 & 4 & 5 \\
\hline 1957, Річардсон & Ідентифікація & Ізоляція & Акомодація & - \\
\hline 1957, Доренвенд, Сміт & Переорієнтація & \begin{tabular}{|c|} 
Повторне підтверджкення, \\
нативізм \\
\end{tabular} & $\begin{array}{c}\text { Часткова } \\
\text { переорієнтація }\end{array}$ & $\begin{array}{l}\text { Відчуження, } \\
\text { відновлення }\end{array}$ \\
\hline 1957, Горобін & Асимільовані & Оглядаються в минуле & Англізовані & Без коріння \\
\hline 1957, Тафт & Асиміляція & - & Акомодація & Маргінальність \\
\hline 1958, Гласер & Асимільовані & Сегреговані & Маргінальні & Десегреговані \\
\hline $\begin{array}{c}\text { 1958, Беннет, Пассін, } \\
\text { МакНайт }\end{array}$ & Ідеаліст & Констриктор & - & Регулятор \\
\hline 1958, Томас & $\begin{array}{l}\text { Індіанці середнього } \\
\text { класу }\end{array}$ & Консервативні індіанці & Генералізовані індіанці & Сільські білі індіанці \\
\hline 1959, Боррі & Асиміляція & Ізоляція & Інтеграція & - \\
\hline 1960, Ротман & Недооцінююча & Переоцінююча & Помірна & Маргінальна \\
\hline 1960, Озубел & Асимілятивна & Рецесивна & Адаптаційна & Дезінтеграція \\
\hline 1961, Херман & Підпорядкування & Відступ та відлучення & $\begin{array}{c}\text { Пристосування та } \\
\text { інтеграція }\end{array}$ & $\begin{array}{c}\text { Вагання } \\
\text { і розчарування }\end{array}$ \\
\hline 1961, Воллас & Асиміляція & Нативізм, націоналізм & Активізація & Нерухомість \\
\hline 1962, Байлін, Кельман & Ідентифікація & Супротив & Погодження & Інтерналізація \\
\hline 1962, Рой & $\begin{array}{c}\text { Амальгамація, } \\
\text { об’єднання, злиття }\end{array}$ & Соціальна сегрегація & Соціальна інтеграція & - \\
\hline 1963, Джонсон & $\begin{array}{c}\text { Суб’єктивна } \\
\text { асиміляція }\end{array}$ & - & Зовнішня асиміляція & - \\
\hline 1963, Неш, Шо & - & Традиційна & Перехідна & Автономна \\
\hline $\begin{array}{l}\text { 1963, Глазер, } \\
\text { Мойніхан }\end{array}$ & $\begin{array}{c}\text { Асиміляція } \\
\text { плавильного котла }\end{array}$ & Культурний плюралізм & $\begin{array}{c}\text { Групи етнічних } \\
\text { інтересів }\end{array}$ & - \\
\hline 1963, Вандер, Занден & Асиміляція & $\begin{array}{c}\text { Агресія, чутливість, } \\
\text { зростання его }\end{array}$ & Акомодація & $\begin{array}{c}\text { Ненависть до себе, } \\
\text { відчуження від реальності }\end{array}$ \\
\hline 1964, Лінтон & Соціокультурне злиття & Нативістичні рухи & $\begin{array}{c}\text { Керовані } \\
\text { культурні зміни }\end{array}$ & - \\
\hline 1964, Гордон & Асиміляція & $\begin{array}{c}\text { Структурний плюра- } \\
\text { лізм } \\
\end{array}$ & Культурний плюралізм & Маргінальність \\
\hline 1965, Форг & Досягнена асиміляція & Досягнена сепарація & $\begin{array}{c}\text { Колоніальний } \\
\text { бікультуралізм } \\
\end{array}$ & $\begin{array}{c}\text { Напівакультурована } \\
\text { маргінальність }\end{array}$ \\
\hline 1966, Кесінг & Асиміляція & Супротив акультурації & $\begin{array}{c}\text { Традиційне суспільство, } \\
\text { симбіотичне }\end{array}$ & Культурне злиття \\
\hline 1967, Лондон & Асиміляція & Плюралізм & Інтеграція & - \\
\hline 1967, Неш & - & Неадаптованість & Зближення & Богемність \\
\hline 1967, Ламберт & Відхилення & Ідентифікація & Неетноцентричність & Амбівалентність \\
\hline 1968, Маден, Мейер & Акультурація & Навітизм & $\begin{array}{c}\text { Стабілізована акульту- } \\
\text { рація }\end{array}$ & Маргінальність \\
\hline 1969, Комо & Провідна акультурація & Можлива акультурація & $\begin{array}{c}\text { Мінімальна } \\
\text { акультурація }\end{array}$ & $\begin{array}{c}\text { Вірогідна } \\
\text { акультурація }\end{array}$ \\
\hline 1969, Рабушка & Міжетнічний шлюб & Етноцентризм & Інтеграція & - \\
\hline 1969, Барт & Асиміляція & Еволюція & - & $\begin{array}{c}\text { Меншість } \\
\text { низького рангу }\end{array}$ \\
\hline 1970, Сарук, Гулустан & $\begin{array}{c}\text { Oрієнтованість на } \\
\text { більшість } \\
\end{array}$ & $\begin{array}{c}\text { Орієнтованість } \\
\text { на меншість } \\
\end{array}$ & $\begin{array}{c}\text { Орієнтованість } \\
\text { на бікультуралізм } \\
\end{array}$ & $\begin{array}{c}\text { Апатична } \\
\text { орієнтованість }\end{array}$ \\
\hline 1970, Peec & Асиміляція & Акомодація & Інтеграція & - \\
\hline 1970, Борн & Інновація & $\begin{array}{l}\text { Ретреатизм, } \\
\text { заперечення }\end{array}$ & Примирення & Абстрагування \\
\hline 1970, Соммеріад, Беррі & Асиміляція & - & Інтеграція & Маргінальність \\
\hline 1970, Берpi & Асиміляція & Заперечення & Інтеграція & Маргінальність \\
\hline 1971, Cy, Cy & - & Традиціоналізм & Азіат-Американець & Маргінал \\
\hline 1972, Гаардер & $\begin{array}{l}\text { Високий статус } \\
\text { одномовності }\end{array}$ & $\begin{array}{l}\text { Низький статус } \\
\text { одномовності }\end{array}$ & $\begin{array}{c}\text { Координований } \\
\text { білінгвізм }\end{array}$ & $\begin{array}{c}\text { Подвійний } \\
\text { напівлінгвізм }\end{array}$ \\
\hline $\begin{array}{c}\text { 1972, Беррі, Еванс, } \\
\text { Ровінсон }\end{array}$ & Асиміляція & $\begin{array}{c}\text { Заперечення, } \\
\text { сегрегація }\end{array}$ & $\begin{array}{c}\text { Інтеграція, колоніа- } \\
\text { лізм } \\
\end{array}$ & Декультурація \\
\hline 1973, Зак & $\begin{array}{c}\text { Негативно-позитивна } \\
\text { реакція } \\
\end{array}$ & $\begin{array}{c}\text { Позитивно-негативна } \\
\text { реакція }\end{array}$ & $\begin{array}{c}\text { Позитивно-позитивна } \\
\text { реакція }\end{array}$ & $\begin{array}{c}\text { Негативно-негативна } \\
\text { реакція }\end{array}$ \\
\hline
\end{tabular}


Продовження таблиці 1

\begin{tabular}{|c|c|c|c|c|}
\hline 1 & 2 & 3 & 4 & 5 \\
\hline 1974, Хант, Вокер & Культурна асиміляція & Культурний плюралізм & Структурна асиміляція & Інтеграція \\
\hline 1974, Петтігру & - & Гетто «Чорної влади» & $\begin{array}{l}\text { Інтеграція, } \\
\text { десегрегація }\end{array}$ & Типове міське гетто \\
\hline 1974, Берpi & Плавильний котел & $\begin{array}{c}\text { Заперечення, вибірко- } \\
\text { ва сегрегація }\end{array}$ & $\begin{array}{c}\text { Інтеграція, батьківська } \\
\text { інтеграція }\end{array}$ & $\begin{array}{l}\text { Маргінальність, } \\
\text { декультурація }\end{array}$ \\
\hline 1975, Вудс & Модифіковані & Традиційні & Ладінізовані & Ладіно \\
\hline 1976, Берpi & Асиміляція & Заперечення & Інтеграція & Декультурація \\
\hline 1976, Шуманн & Асиміляція & $\begin{array}{l}\text { Консервація, збере- } \\
\text { ження } \\
\end{array}$ & Акультурація & - \\
\hline $\begin{array}{c}\text { 1976, Кларк, } \\
\text { Кауфман, П’єрс }\end{array}$ & $\begin{array}{c}\text { Висока самоідентифі- } \\
\text { кація з контактуючою } \\
\text { культурою } \\
\end{array}$ & $\begin{array}{c}\text { Прагнучі повернутися } \\
\text { до витоків } \\
\text { власної культури } \\
\end{array}$ & Бікультурні & Ізольовані \\
\hline 1976, Дрідгер & $\begin{array}{c}\text { Більшість асимільо- } \\
\text { ваних }\end{array}$ & Етнічно ідентифіковані & - & Культурно маргінальні \\
\hline 1976, Вагнер & - & Традиційні & $\begin{array}{l}\text { Транзитні, американ- } \\
\text { ський середній клас }\end{array}$ & - \\
\hline $\begin{array}{l}\text { 1977, Беррі, Каллін, } \\
\text { Тейлор }\end{array}$ & Асиміляція & Заперечення & $\begin{array}{c}\text { Інтеграція, теорія } \\
\text { мультикультуралізму }\end{array}$ & Декультурація \\
\hline 1977, Спіндлер & Наслідування & Збереження кордонів & $\begin{array}{c}\text { Бікультуралізм, } \\
\text { синтез, керовані іден- } \\
\text { тичності } \\
\end{array}$ & - \\
\hline $\begin{array}{l}\text { 1978, Кларк, } \\
\text { Кауфман, Пірс }\end{array}$ & - & Тип 5 & Типи $2,3,4,6$ & Тип 1 \\
\hline 1979, Каміллері & - & $\begin{array}{c}\text { Свідома підтримка } \\
\text { традиційних цінностей } \\
\text { та культури }\end{array}$ & $\begin{array}{l}\text { Прагнення до синтезу } \\
\text { культур, зокрема тих } \\
\text { аспектів приймаючої } \\
\text { культури, які спри- } \\
\text { яють соціальному та } \\
\text { економічному розвитку } \\
\end{array}$ & $\begin{array}{c}\text { Заперечення нових } \\
\text { цінностей та втрата } \\
\text { своєї традиційної } \\
\text { культури }\end{array}$ \\
\hline 1979, Коен-Емерік & Модерні & Традиційні & - & Невизначені \\
\hline 1980, Канг & Асиміляція & Традиціоналізм & Бількультурність & Маргінальність \\
\hline 1980, Фішмен & $\begin{array}{c}\text { Моноглосія } \\
\text { і монолінгвізм }\end{array}$ & $\begin{array}{c}\text { Диглосія } \\
\text { і монолінгвізм }\end{array}$ & Диглосія і білінгвізм & Моноглосія і білінгвізм \\
\hline $\begin{array}{c}\text { 1980, Шапочник, } \\
\text { Куртинец, Фернандес }\end{array}$ & $\begin{array}{c}\text { Причетні до єдиної } \\
\text { культури }\end{array}$ & $\begin{array}{c}\text { Причетні до єдиної } \\
\text { культури }\end{array}$ & $\begin{array}{c}\text { Причетні до двох } \\
\text { культур }\end{array}$ & $\begin{array}{c}\text { Не причетні до жодної } \\
\text { культури }\end{array}$ \\
\hline 1980, Беррі & $\begin{array}{c}\text { Асиміляція, } \\
\text { плавильний котел }\end{array}$ & $\begin{array}{c}\text { Заперечення, } \\
\text { сегрегація }\end{array}$ & $\begin{array}{c}\text { Інтеграція, } \\
\text { мультикультуралізм, } \\
\text { плюралізм } \\
\end{array}$ & $\begin{array}{c}\text { Декультурація, } \\
\text { маргінальність, } \\
\text { етноцид } \\
\end{array}$ \\
\hline 1980, Паділла & Англіцизм & Неакультурація & Помірність & - \\
\hline 1980, Абрамсон & Трансформація & Традиціоналізм & Вигнання & Недоступність \\
\hline 1981, Тафт & $\begin{array}{c}\text { Маргінальність через } \\
\text { асиміляцію }\end{array}$ & $\begin{array}{l}\text { Маргінальність через } \\
\text { множинну сепарацію }\end{array}$ & $\begin{array}{c}\text { Маргінальність через } \\
\text { посередництво чи мно- } \\
\text { жинну інтеграцію } \\
\end{array}$ & Ізоляція \\
\hline 1981, Троспер & Перенесення & Автономність & Контакт & Відчуження \\
\hline 1981, Бантон & Конформізм & Колоніальність & Перехідна реакція & Ізоляція \\
\hline 1982, Бошнер & Асиміляція & Сегрегація & Інтеграція & - \\
\hline 1982, Шмітер & $\begin{array}{c}\text { Асиміляція, вини- } \\
\text { щення } \\
\end{array}$ & Сегрегація & Плюралізм & Маргінальність \\
\hline 1983, Беррі & Асиміляція & Заперечення, опір & Інтеграція & $\begin{array}{l}\text { Декультурація, } \\
\text { маргінальність }\end{array}$ \\
\hline $\begin{array}{c}\text { 1984, Беррі, Кiм, Янг, } \\
\text { Буджакі }\end{array}$ & Асиміляція & Сепарація & Інтеграція & Маргінальність \\
\hline 1986, Шуманн & Асиміляція & Консервація & Адаптація & - \\
\hline $\begin{array}{c}\text { 1986, Тріадіс, Кашима, } \\
\text { Шимада, Вілареал }\end{array}$ & Акомодація & Етнічна прихильність & - & - \\
\hline 1987, Нелд & Асиміляція & Опір & Інтеграція & - \\
\hline 1988, Могаддам & $\begin{array}{c}\text { Нормативна } \\
\text { асиміляція }\end{array}$ & \begin{tabular}{|c|} 
Ненормативне \\
збереження культурної \\
спадщини
\end{tabular} & \begin{tabular}{|c} 
Нормативне \\
збереження культурної \\
спадщини
\end{tabular} & $\begin{array}{l}\text { Ненормативна } \\
\text { асиміляція }\end{array}$ \\
\hline $\begin{array}{l}\text { 1988, Содомський, } \\
\text { Карі }\end{array}$ & $\begin{array}{c}\text { Дуже американська, } \\
\text { переважно } \\
\text { американська } \\
\end{array}$ & $\begin{array}{c}\text { Провінціальна, } \\
\text { Азіатсько-Індіанська }\end{array}$ & Бікультуральна & - \\
\hline
\end{tabular}


Закінчення таблиці 1

\begin{tabular}{|c|c|c|c|c|}
\hline 1 & 2 & 3 & 4 & 5 \\
\hline 1991, Хатнік & Асимілятивна & Дисоціативна & Акультураційна & Маргінальна \\
\hline 1992, Мертон & $\begin{array}{l}\text { Конформність, } \\
\text { інновація }\end{array}$ & $\begin{array}{c}\text { Ритуалізм, ретритизм } \\
\text { (ескейпізм) }\end{array}$ & - & Бунт \\
\hline $\begin{array}{l}\text { 1993, ЛяФрамбуаз, } \\
\text { Колеман, Гертон }\end{array}$ & Асиміляція & - & $\begin{array}{c}\text { Чергування, злиття, } \\
\text { мультикультуралізм, } \\
\text { акультурація }\end{array}$ & - \\
\hline 1993, Саєг, Ларсі & Асиміляція & Етноцентризм & Інтеграція & Маргіналізація \\
\hline 1994, Донченко & Ідентифікація & $\begin{array}{l}\text { Індивідуалізація, } \\
\text { маргіналізація }\end{array}$ & Інвестиція & Девіація \\
\hline 1995, Кольман & $\begin{array}{c}\text { Акультурація, моно- } \\
\text { культуралізм } \\
\end{array}$ & Сепарація & Інтеграція, чергування & Злиття \\
\hline 1995, ДеВос & $\begin{array}{c}\text { Функціональна, пере- } \\
\text { хідна адаптація }\end{array}$ & $\begin{array}{c}\text { Сімейно-культурна } \\
\text { адаптація } \\
\end{array}$ & $\begin{array}{c}\text { Трудова адаптація, } \\
\text { акомодація } \\
\end{array}$ & Ідеологія, відчуження \\
\hline $\begin{array}{l}\text { 1997, Буріс, Моic, } \\
\text { Перо, Сенекаль }\end{array}$ & Асиміляція & $\begin{array}{c}\text { Збереження етнічності, } \\
\text { сепаратизм }\end{array}$ & Плюралізм, інтеграція & $\begin{array}{c}\text { Цивільна позиція, } \\
\text { аномія, індивідуалізм, } \\
\text { екслюзія }\end{array}$ \\
\hline 1999, Ямада, Зінгеліс & Західна & Традиційна & Бікультурна & Культурно-відчужена \\
\hline 2000, Фаіст & Асиміляція & - & $\begin{array}{c}\text { Етнічний плюралізм, } \\
\text { перетин кордонів }\end{array}$ & - \\
\hline $\begin{array}{l}\text { 2001, Рудмін, Амад- } \\
\text { жадех }\end{array}$ & Асиміляція & Сепарація & Інтеграція & Мультикультуралізм \\
\hline 2001, Берpi & Асиміляція & Сепарація, сегрегація & $\begin{array}{c}\text { Інтеграція, мультикул- } \\
\text { туралізм } \\
\end{array}$ & Ексклюзія \\
\hline 2001, Монтрьой, Буріс & Асиміляціоністи & Сегрегаціоністи & Інтеграціоналісти & $\begin{array}{l}\text { Індивідуалісти, } \\
\text { ексклюзіоністи }\end{array}$ \\
\hline $\begin{array}{c}\text { 2001, Уденховен, } \\
\text { Ван Дер Зее, } \\
\text { Ван Коотен }\end{array}$ & $\begin{array}{l}\text { Експатріанти - прибіч- } \\
\text { ники місцевої компанії }\end{array}$ & $\begin{array}{c}\text { Експатріанти - } \\
\text { прибічникиматеринської } \\
\text { компанії }\end{array}$ & Подвійне громадянство & Вільні агенти \\
\hline 2001, Брубакер & Право бути іншим & $\begin{array}{c}\text { Політика на користь } \\
\text { іноземців }\end{array}$ & Диференціалізм & Право на байдужість \\
\hline $\begin{array}{l}\text { 2002, Унгер, Галлахер, } \\
\text { Шакіб }\end{array}$ & \begin{tabular}{|c|} 
Opiєнтація на прийма- \\
ючу країну
\end{tabular} & $\begin{array}{c}\text { Oрієнтація на інші } \\
\text { країни } \\
\end{array}$ & $\begin{array}{l}\text { Opiєнтація на обидві } \\
\text { країни } \\
\end{array}$ & $\begin{array}{c}\text { Відсутність орієнтації } \\
\text { на жодну з країн }\end{array}$ \\
\hline 2003, Рудігер, Спенсер & Асиміляція & - & $\begin{array}{c}\text { Включення, } \\
\text { мультикультуралізм, } \\
\text { злиття, рівність } \\
\end{array}$ & - \\
\hline 2005, Горовіц & $\begin{array}{l}\text { Гібридний стан, } \\
\text { асиміляція }\end{array}$ & $\begin{array}{l}\text { Гібридний стан, } \\
\text { сепарація }\end{array}$ & $\begin{array}{c}\text { Гібридний стан, } \\
\text { інтеграція, } \\
\text { інтернаціоналізація }\end{array}$ & Гібридний стан \\
\hline $\begin{array}{l}\text { 2011, Володько, } \\
\text { Ровенчак }\end{array}$ & Асиміляція, сегрегація & Добровільна сегрегація & Творення діаспор & Протест \\
\hline
\end{tabular}

рамок та установок власної культури та водночас упередженням та внутрішнім конфліктом щодо приймаючої культури.

4) Четвертий можливий стан культурного гібрида $(+\mathrm{BK}+\Pi К)$ характеризується спільною участю в культурному житті двох різних народів, не готових залишити свої минулі традиції, однак відкриті для культури приймаючої спільноти.

У 1936 році американськими антропологами Р. Редфілдом, М. Герсковіцем та Р. Лінтоном були розроблені теоретичні положення процесу акультурації та адаптації на основі вивчення впливу англо-саксонської культури на місцеве населення індіанців та примусових іммігрантів африканського походження. Вони зосередили свою увагу на тому, як різні види спільнот, відносин та політики приймаючої групи впливають на процес акультурації. Науковцями були введені поняття «донор- ських та реципієнтних спільнот», згідно з якими реципієнтна (приймаюча) спільнота адаптується, відмежовується або асимілюється 3 донорською (іммігрантською) залежно від її мирного чи ворожого взаємовпливу одна на одну, внаслідок чого відбуваються «культурні зміни», що позначають нав'язування або прийняття елементів чужорідної культури культурі реципієнтної спільноти [5, с. 149-152].

Відповідно до характеру культурних змін, Р. Редфілдом, М. Герсковіцем та Р. Лінтоном були виділені три адаптаційні моделі акультурації.

1) Модель прийняття (-ВК + ПК) елементів приймаючої спільноти, згідно 3 якою процес акультурації відбувається через прийняття більшої частини елементів приймаючої культури та втрату більшої частини власної культурної спадщини з мовчазної згоди членів приймаючої групи, 
як наслідок, відбувається засвоєння ними не тільки моделей поведінки, але й цінностей культури, 3 якою вони вступили в контакт.

2) Модель реакції (+ВК -ПК) на донорську спільноту (або сепарації), згідно з якою приймаюче місцеве населення чинить контрадаптаційний опір пригнобленню його власної культури та примусовому нав'язуванню елементів чужорідної культури.

3) Модель адаптації (+BК +ПК) до приймаючої спільноти, згідно з якою поєднуються елементи як донорської, так і приймаючої культури в процесі їх гармонійної співпраці або примирення конфліктних точок зору та ситуацій задля утворення функціонального культурного цілого.

М. Кларк, Ш. Кауфман та Р. Пірс у 1978 році на основі емпіричних досліджень щодо мексиканських та японських мігрантів у США запропонували шість адаптаційних моделей акультурації. Соціологами було розроблено такі три шкали адаптаційної орієнтації:

- традиційна орієнтація, тобто рівень знань та поведінки в рамках власної культури;

- американська орієнтація, тобто рівень знань та поведінки в рамках приймаючої культури;

- шкала адаптаційного балансу, де високий бал вказував на відносно вищий рівень знань про приймаючу культуру, ніж про власну, а низький бал - на вищий рівень знань власної культури, ніж приймаючої.

Кластерний аналіз трьох шкал показників привів до створення шести емпірично перевірених типів (моделей) адаптаційної поведінки. ЖЖодна 3 них не виразила модель асиміляції $(-\mathrm{BK}+\Pi К)$, зазвичай присутню в «ідеальному конструкті» моделей адаптації, натомість кластерний аналіз дав змогу виділити чотири різні моделі бікультуралізму (рис. 3) [2, с. 233-236].
Модель 1 (-ВК -ПК) - несумісність знань і поведінки 3 набагато вищим рівнем знань власної культури, ніж американської, але набагато вищим рівнем поведінки в рамках американської, ніж власної.

Модель 5 (+ВК -ПК) - вищий рівень знань про приймаючу культуру, ніж власну, але дуже високий рівень поведінки в рамках власної культури та дуже низький рівень поведінки в рамках культури приймаючого середовища.

Модель $2(+\mathrm{BK}+\Pi \kappa)$ - набагато вищий рівень знань про власну традиційну культуру, ніж про приймаючу, але помірно високий та збалансований рівень участі в рамках обох культур.

Модель $3(+\mathrm{BK}+\Pi К)$ - збалансований рівень знань двох культур і трохи вищий рівень участі в рамках приймаючої культури, ніж власної культури.

Модель $4(+\mathrm{BK}+\Pi К)$ - збалансований рівень знань двох культур, однак трохи нижчий рівень участі в американській культурі.

Модель $6(+\mathrm{F}+\mathrm{C})$ - вищий рівень знань американської культури, ніж власної, але дуже високий і рівний рівень участі в рамках обох культур.

У 2003 році дослідники А. Рудігер та С. Спенсер запропонували п'ять адаптаційних моделей, котрі науковці назвали концепціями соціальної інтеграції мігрантів, однак якщо застосувати до цих моделей конструкт чотирьох моделей Ф.В. Рудміна, то чотири з п'яти запропонованих моделей А. Рудіґера та С. Спенсера зосереджені на варіаціях бікультурного співіснування власної і приймаючої культур $(+\mathrm{BK}+\Pi К)$.

1) Асиміляція (-ВК +ПК) - односторонній процес засвоєння іммігрантом уже наявного соціального порядку, гомогенної культури та набору цінностей, який передбачає зміни, що стосуються лише іммігранта.



Рис. 3. Моделі адаптації (М. Кларк, Ш. Кауфаман, Р. Пірс, 1978 рік) 
2) Включення та участь $(+\mathrm{BК}+\Pi К)-$ двосторонній процес взаємодії суспільства, що приймає, та іммігрантів через їхню участь у різних сферах життя суспільства. Однак часто іммігрант опиняється у ситуації, коли він інтегрований у певні сфери суспільства (наприклад, у ринок праці) за одночасного вилучення з інших (наприклад, із політичного процесу).

3) Злиття $(+\mathrm{BK}+\Pi К)$ - це не розчинення іммігрантських спільнот в однорідному суспільстві, а «соціальне злиття» у плюралістичному суспільстві, що досягається через взаємодію різних спільнот, яке передбачає визнання відмінностей та взаємозалежності цими спільнотами.

4) Рівність $(+\mathrm{BK}+\Pi К)$ - це свого роду доповнена концепція «злиття», оскільки тут взаємодія різних іммігрантських спільнот та суспільства, що приймає, відбувається на підставі взаємного визнання рівності, рівноправного доступу до соціальних ресурсів, інституцій, механізмів вирішення конфліктів та відповідальності за процеси, які відбуваються в цьому суспільстві. У цьому разі конфлікти, які грунтуються на відмінностях цінностей, вирішують за допомогою демократичного механізму переговорів та примирень, що відкритий для всіх спільнот.

5) Мультикультуралізм (+ВК $+\Pi К)$ - концепція інтеграції, яка передбачає визнання культурних відмінностей спільнот і регулювання їх за принципом рівноправності. У цьому разі не підтримується ні стирання культурних кордонів, ні їхне укріплення, натомість підтримується посилення проникності цих кордонів та полегшення участі всіх груп у всіх сферах суспільного, економічного, культурного, політичного життя, що робить можливим безболісне подолання проблем, пов'язаних із відмінностями та явищами сегрегації $[6$, с. 4-7].

Отже, протягом XX століття низка дослідників у царині міжкультурних взаємин використовувала та удосконалювала методики вивчення адаптації мігрантів, проте здебільшого вони дотримувались конструкту чотирьох основних адаптаційних моделей, зважуючи на необхідність розширення адаптаційних альтернатив.

Так, у 2003 році Ф.В. Рудмін проводить критичний аналіз традиційної концепції чотирьох моделей адаптації і доходить висновку, що більшість наявних конструктів адаптаційних моделей (табл. 1), як правило, не були ні продовженнями, ні вдосконаленням попередніх концепцій, але пропонувались як авторські розробки. Згідно з Ф.В. Рудміним, у середньому вчені, що пропонують типологію чотирьох класичних моделей адаптації, цитують лише $5 \%$ своїх попередників, майже половина наявних концепцій адаптаційних моделей позиціонується як оригінальні винаходи, оскільки вони не включають посилань на жодну з попередніх концепцій [7, с. 16].

Піддаючи сумніву релевантність класичних чотирьох адаптаційних моделей, Ф.В. Рудмін зміг виокремити 16 моделей адаптації. Дослідник апелює до висновку про те, що наявність двох культур, двох ідентичностей або двох мов супроводжується наявністю подібних культурних, технічних, побутових та психологічних елементів, а також елементів, яких немає в жодній з двох культур. Ідея автора походить від припущення, що дві культури можуть мати низку спільних культурних рис; культурний вибір індивіда не є обмеженим лише двома культурами, але може включати елементи третьої та інших культур; перевагу у виборі та практиці елементів інших культур можна виражати з використанням багатоваріативності їх поєднання [7, с. 25-26].

Також у 2005 році ізраїльський соціолог Т. Горовіц на основі емпіричних досліджень іммігрантів з пострадянських країн, поділяючи думку Ф.В. Рудміна, наголосив на тому, що жодна з класичних чотирьох моделей адаптації не $є$ домінуючою серед мігрантів з пострадянського регіону в Ізраїлі, оскільки адаптаційні моделі мігрантів з колишніх радянських країн можуть включати елементи декількох моделей одночасно. Отже, Т. Горовіц вводить поняття адаптаційного сценарію як аналогу адаптаційної моделі, підкреслюючи, що сценарій може не лише поєднувати елементи різних адаптаційних моделей, але й змінюватись із часом залежно від внутрішніх та зовнішніх чинників впливу на процес адаптації іммігранта в новому для нього середовищі. Під внутрішніми чинниками науковець розуміє об'єктивний та суб'єктивний особистісний капітал, зокрема наявність економічних, психологічних та освітніх ресурсів мігрантів. До зовнішніх соціолог відносить зміну міграційної політики країни Ізраїль протягом певного періоду часу, динаміку відкритості соціальних структур та інститутів, економічні та соціальні зв'язки мігрантів з країною їх походження, особливості ставлення до мігрантів у приймаючих спільнотах, котрі, з точки зору соціології як науки, можуть мати набагато більший вплив, ніж особистісні внутрішні чинники [3, с. 127-135].

Т. Горовіц пропонує такі адаптаційні сценарії.

1) Сценарій асиміляції $(-В К+П К)$, відповідно до якого із самого початку ідеї створення держави Ізраїль нові іммігранти мали на меті відділитися від норм і цінностей своєї старої країни та сформувати, розвити і прийняти норми та цінності ізраїльського суспільства, розвиваючи нову ідентичність.

2) Сценарій сепарації (+ВК $-\Pi К)$, відповідно до якого іммігранти мали багате культурне життя у колишній країні перебування, тому мають на меті не лише перенести свою культурну спадщину 
в Ізраїль, але й долучити до неї приймаючу спільноту.

3) Сценарій інтеграції або інтернаціоналізації $(+\mathrm{BK}+\Pi \kappa)$, відповідно до якого іммігранти воліють зберігати подвійне громадянство та ідентифікують свою приналежність одночасно до двох і більше різних культур (зокрема, української, ізраїльської та радянської чи української, ізраїльської та американської).

4) Сценарій гібридної адаптації, відповідно до якого в різний період часу, для різних вікових груп адаптаційні сценарії можуть змінювати один одного залежно від намірів: від асиміляції $(-\mathrm{BK}+\Pi К)$ до сепарації (+ВК -ПК) або інтеграції $(+B K+\Pi К)$. ОКрім того, гібридний сценарій адаптації іммігрантів передбачає вагомий вплив культури іммігрантів на місцеву культуру до рівня їх злиття.

Із сучасних вітчизняних соціологів хотілося б відзначити таких, як В. Володько та О. Ровенчак, головний внесок яких полягає не лише в розробленні авторських моделей адаптації, але й у їх кореляції з видами державної політики адаптації мігрантів у приймаючому суспільстві та «моделями реакцій» приймаючих спільнот на спільноти іммігрантів [11, с. 194-199].

Адаптаційні «двосторонні моделі адаптації, які запропонували В. Володько та О. Ровенчак, $€$ такими.

1) Модель протесту з боку мігрантів (+ВК -ПК) передбачає активний протест проти насадження норм і цінностей приймаючої культури; з боку приймаючої спільноти (-BК +ПК) передбачає реакцію супротиву імміграційних потоків у країну, прояв ксенофобії та заперечення норм і цінностей спільнот іммігрантів.

2) Модель добровільної сегрегації з боку мігрантів (+ВК -ПК) передбачає добровільне відгородження від норм і цінностей приймаючої культури; з боку приймаючої спільноти $(+\mathrm{BK}+\Pi \kappa)$ передбачає реакцію часткового прийняття норм $\mathrm{i}$ цінностей іммігрантських спільнот.

3) Модель творення діаспор з боку мігрантів (+ВК +ПК) передбачає часткове прийняття норм і цінностей приймаючої культури разом зі своїми власними; з боку приймаючої спільноти $(+\mathrm{BK}+\Pi \kappa)$ передбачає реакцію часткового прийняття норм і цінностей іммігрантських спільнот разом з уже чинними в суспільстві.

4) Модель сегрегації 3 боку мігрантів $(+\mathrm{BK}+\Pi \kappa)$ передбачає часткове прийняття норм і цінностей приймаючої культури; з боку приймаючої спільноти (-ВК $+\Pi К)$ передбачає реакцію заперечення норм і цінностей іммігрантських спільнот, намагання відгородити їх від суспільства.

5) Модель маргіналізації 3 боку мігрантів (-ВК -ПК) передбачає неуспішне прийняття норм i цінностей приймаючої культури та відмову від своїх власних; з боку приймаючої спільноти
(-ВК +ПК) передбачає реакцію заперечення норм i цінностей іммігрантських спільнот, намагання асимілювати їх із приймаючим суспільством [11, с. 194--199].

На думку автора, з названих та проаналізованих моделей адаптації саме адаптаційні «сценаpiï» (Т. Горовіц), «реакції» приймаючого суспільства на іммігрантів (В. Володько, О. Ровенчак) та адаптаційні «типи» (М. Кларк, Ш. Кауфман та P. Пірс) заслуговують на особливу увагу як одні з розширених конструктів соціологічних адаптаційних моделей мігрантів в іншокультурному середовищі, оскільки звертаються до поглибленого аналізу як зовнішніх, так і внутрішніх чинників, що впливають на процес адаптації та вирізняють декілька можливих рівнів, станів, реакцій на співіснування в умовах бі- або мультикультуралізму.

Як висновок відзначимо, що емпіричні дослідження адаптаційних моделей розпочались у 1918 році з вивченням В. Томасом та Ф. Знанецьким польських мігрантів у США та не втрачають своєї актуальності досі. 3 того часу так чи інакше більшість дослідників вирізняє «ідеальний конструкт» адаптаційних моделей, що складається з таких чотирьох моделей адаптації іммігрантів до приймаючого суспільства:

1) асиміляція (-ВК +ПК) - повне прийняття умов суспільства країни міграції, його норм, цінностей та культури і відмова від власних;

2) сепарація (+ВК -ПК) - повна відмова прийняти вимоги, норми, цінності та культуру нового суспільства, натомість повне збереження власних ціннісних преференцій та культурно-побутових практик;

3) інтеграція (бі- мультикультуралізм) $(+\mathrm{BK}+\Pi К)$ - часткове прийняття нового суспільства, що виявляється у згоді інтеріорізувати його обов'язкові норми, закони, цінності та культуру, при цьому зберегти свої власні ціннісні орієнтири;

4) маргіналізація (-ВК -ПК) - відмова від власних норм, цінностей та культури і несприйняття нових, загальноприйнятих у новому суспільстві.

Винятком є науковці, котрі пропонують розширену кількість та інтерпретацію адаптаційних моделей, зокрема соціологи М. Кларк, Ш. Кауфман, Р. Пірс, Ф.В. Рудмін, Т. Горовіц, В. Володько, О. Ровенчак, звертаючи особливу увагу як на внутрішні, так і на зовнішні чинники, що впливають на процес адаптації, пропонуючи вийти за межі ідеального конструкту чотирьох класичних моделей адаптації та приділити більше уваги саме бікультурним варіаціям адаптаційних моделей.

Однак, ймовірно, частіше теоретизують не самі моделі, а їх змінні, оскільки більшість наявних конструктів адаптаційних моделей, як правило, не виступають ні продовженнями, ні вдосконаленням попередніх концепцій, а пропонуються як авторські розробки, оскільки не посилаються на жодну з попередніх концепцій. 
Дослідницькі спільноти з питань соціокультурної адаптації, ймовірно, продовжуватимуть створювати нові концепції адаптаційних моделей, оскільки кожне нове поєднання двох чи більше культур за певних зовнішніх соціальних, політичних та економічних обставин потребуватиме унікальних питань щодо конкретних міжкультурних меж взаємодії. Однак краща інтеграція та поширення наявних дослідницьких доробків можуть зробити наявні концепції більш відомими і тим самим закласти фундамент для нових емпіричних досліджень на їх основі.

\section{Jimepamypa}

1. Berry J., Kim U., Minde T., Mok D. Comparative Studies of Acculturative Stress. International Migration Review. 1987. № 21. P. 491-511.

2. Clark M., Kaufman S., Pierce R.C. Explorations of acculturation: Toward a model of ethnic identity. Human Organization. 1976. № 35. P. 231-238.

3. Horowitz T. The Integration of Immigrants from the Former Soviet Union. Israel Affairs. 2005. № 11 (1). P. 117-136.

4. Park R.E. Human migrations and the marginal man. American Journal of Sociology. 1928. № 33. P. 881-893.

5. RedfieldR.,LintonR.,Herskovits M.Memorandum on the Study of Acculturation. American Anthropologist. 1936. № 38. P. 149-152.

6. Rudiger A., Spenser S. Social Integration of Migrants and Ethnic Minorities. Policies to Combat Discrimination. The Economic and Social Aspects of Migration: Conference Jointly organized by The European Commission and the OECD. 2003. URL: www.oecd.org/ dataoecd/15/4/15516956.pdf.

7. Rudmin F.W. Critical History of the Acculturation. Psychology of Assimilation, Separation, Integration, and Marginalization. Review of General Psychology. 2003. № 7 (1). P. 3-37.

8. Rudmin F.W. Catalogue of Acculturation Constructs: Descriptions of 126 Taxonomies, 1918-2003. Online Readings in Psychology and Culture. 2009. URL: https://scholarworks.gvsu.edu/orpc/vol8/iss1/8.

9. Thomas W.I., Znaniecki F. Introduction, in Part IV: Life Record of an Immigrant of the Polish Peasant in Europe and America. New York, 1958. URL: https://brocku.ca/MeadProject/Thomas/Thomas_1918/ Thomas 1918d.html.

10.Блинова О. Соціально-психологічна адаптація вимушених мігрантів: підходи і проблеми вивчення феномена акультурації. Науковий вісник Херсонського державного університету. Серія: Психологічні науки. 2016. № 3. С. 111-117.

11. Володько В., Ровенчак О. Моделі соціокультурної адаптації іммігрантів. Вісник Львівського універсиmemy. 2008. № 2. C. 182-210.

12. Завацька Н. Особливості соціальної підтримки в осіб з різним ступенем соціальної адаптації. Актуальні проблеми психологї̈. 2010. № 8 (7). С. 90-105.

13. Міграційні процеси в сучасному світі: світовий, регіональний та національний виміри: Понятійний апарат, концептуальні підходи, теорія та практика : енциклопедія / упоряд. Ю. Римаренко. Київ : Довіра, 1998. 912 с.

14. Соціологія : короткий енциклопедичний словник / за заг. ред. В. Воловича. Київ : Український центр духовної культури, 1998. 736 с.

\section{Анотація}

Плющ В. А. Соціологічні моделі соціокультурної адаптації сучасних мігрантів в іншокультурному середовищі. - Стаття.

Стаття присвячена теоретичному аналізу вивчення проблеми соціокультурної адаптації мігрантів в іншокультурному середовищі. Розглянуто поняття соціокультурної адаптації та акультурації, окреслено кореляцію між цими двома поняттями та їх взаємозалежність. Надано узагальнену міждисциплінарну теоретичну типологізацію моделей адаптації від початку ХХ століття до сьогодення, що нараховує більше 120 варіацій конструктів моделей адаптації. Зроблено висновки про те, що, незважаючи на значну кількість наявних конструктів моделей адаптації, більшість авторів схиляється до так званого ідеального конструкту, що складається 3 чотирьох моделей адаптації мігрантів до приймаючого середовища, а саме асиміляції, тобто повного прийняття умов суспільства країни міграції, його норм, цінностей та культури і відмови від власних; сепарації, тобто повної відмови прийняти вимоги, норми, цінності та культуру нового суспільства, натомість повного збереження власних ціннісних преференцій та культурно-побутових практик; інтеграції, тобто часткового прийняття культурних кодів нового суспільства та збереження власних ціннісних орієнтацій; маргіналізації, тобто відмови від власних норм, цінностей та культури і несприйняття нових, загальноприйнятих у новому суспільстві. Проаналізовано головні концептуальні ідеї дослідників адаптаційних конструктів, найбільш дотичних до соціологічних емпіричних досліджень. Особливу увагу приділено соціологам, котрі виходять за рамки ідеального конструкту чотирьох моделей адаптації та пропонують розширені варіанти адаптаційних конструктів за рахунок поглибленого вивчення бі- або мультикультурних адаптаційних моделей внаслідок двостороннього впливу на процес адаптації як з боку спільноти, що адаптується, так і з боку суспільства, що приймає. Виявлено, що лише невелика частина наявних адаптаційних конструктів цитується авторами кожного нового конструкту, що спонукає до необхідності поширення інформації про наявні адаптаційні конструкти для їх подальшого поглибленого вивчення та емпіричної верифікації.

Ключові слова: адаптаційні моделі, адаптаційний конструкт, акультурація, міжкультурна взаємодія, адаптаційний сценарій. 


\section{Summary}

Pliushch V. A. Sociological models of sociocultural adaptation of modern migrants in new cultural environment. - Article.

The purpose of this article is to analyze theoretical problems of sociocultural adaptation of migrants in new cultural environment. Correlation and interdependence of the concepts of sociocultural adaptation and acculturation are analyzed. The interdisciplinary theoretical typology with more than 120 theoretical constructs of models of adaptation is presented. The typology includes the theoretical constructs dating from the beginning of the XX century to the present times. Despite the significant number of existing constructs of models of adaptation, most authors tend to use so-called "ideal construct", consisting of four models of adaptation for immigrants in a new cultural environment: 1) assimilation, accepting by immigrants norms, values and culture of a new cultural society while rejecting their own cultural values and norms; 2) segregation, refusing by immigrants to accept the requirements, norms, values and culture of a new society, instead preserving their own value preferences and cultural practices; 3) integration, partially accepting by immigrants the values of a new society, while partially keeping their own cultural values too; 4) marginalization, rejecting by immigrants both their own norms, values and culture, as well as values and norms of new society too. The main conceptual ideas of researchers most relevant to sociological empirical studies are analyzed. Particular attention is paid to sociologists offering expanded versions of constructs of models of adaptation through in-depth study of bi- or multicultural adaptation models due to bilateral impact on adaptation process by both native and host cultures. It was found that only a small part of the existing concepts of adaptation is cited by the authors of every new construct of models of adaptation, which encourages spreading information about existing constructs of models of adaptation for their further in-depth study and empirical verification.

Key words: adaptation models, adaptation construct, acculturation, intercultural interaction, adaptation scenario. 